Final Accepted Pre-Proof Version:

Publication Citation:

Perry, J. Adam. (2019). "Images of work, images of defiance: Engaging migrant farm worker voice through community-based arts.” Agriculture and Human Values, 36 (3), pp 627-640. https://doi.org/10.1007/s10460-018-9861-9

\title{
Images of work, images of defiance: Engaging migrant farm worker voice through community-based arts
}

\section{J. Adam Perry}

\begin{abstract}
This article addresses a stated need within the food justice movement scholarship to increase the attention paid to the political socialization of hired farm hands in industrial agriculture. In Canada, tackling the problem of farm worker equity has particular social and political contours related to the Canadian horticultural industry's reliance on a state-managed migrant agricultural labour program designed to fill the sector's labour market demands. As Canada's Seasonal Agricultural Worker Program (SAWP) produces relations of 'unfree labour', engaging migrant farm workers in social movement initiatives can be particularly challenging. Critical educational interventions designed to encourage migrant farm workers' contribution to contemporary social movements in Canada must therefore confront the socio-cultural obstacles that constrict migrant farm workers' opportunities to participate as full members of their communities. In this article, I argue that social justice oriented approaches to community-based arts can provide a means for increasing the social movement contributions of farm workers employed through managed labour migration schema such as Canada's SAWP.
\end{abstract}

\section{Abbreviations \\ SAWP Seasonal Agricultural Worker Program}

Keywords Migrant farm workers; Theatre of the Oppressed; Seasonal Agricultural Workers Program; guest worker programs; unfree labour; Canada

\author{
J. Adam Perry \\ contact@adamperry.ca
}

School of Social Work/School of the Arts, McMaster University, Togo Salmon Hall 410, 1280 Main Street West, Hamilton, Ontario, L8S 4M4, Canada

J. Adam Perry (www.adamperry.ca) is a Postdoctoral Research Fellow cross appointed between the School of the Arts and the School Social Work at McMaster University in Hamilton, Canada. His research interests include migrant justice, migrant mobility, 
immigration policy, precarious work, employment policy, and community-based arts practice.

Acknowledgements The author wishes to gratefully acknowledge the helpful comments of the three anonymous reviewers during the preparation of this manuscript.

\section{Introduction}

Community-based cultural production can be a powerful tool for the political socialization of hired farm workers in industrial agriculture. With a focus on Canada's Seasonal Agricultural Worker Program (SAWP), a bi-lateral guest worker regime between Canada, Mexico, and several Caribbean countries, in this article I assess the grassroots organizational potential of directly engaging migrant farm workers in an artistic and collective exploration of their daily lives. In response to a growing literature that laments the lack of attention paid to farm worker equity in the food justice movement, in this article I argue that social justice oriented approaches to communitybased arts can provide a way to increase the social movement contributions of farm workers employed through managed migration schema such as Canada's SAWP. I develop this argument from an analysis of participant observation extracted from a community-arts project that I conducted with a small group of SAWP workers in the Southwestern Ontario town of Leamington, a major hub of Canada's horticultural greenhouse industry. This project was grounded in the practice of Theatre of the Oppressed, a well-known arts-based adult education tool designed by the late Brazilian educator and theatre director Augusto Boal for engaging non-actors from traditionally marginalized communities as a means of supporting social and political change. While it has been established in the extant literature that engaging SAWP workers in migrant and food justice activism can be an excessively difficult task, it is becoming more widely recognized by food justice activists and scholars that doing so is imperative to developing an inclusive and equitable movement.

While critical artistic interventions have not been widely employed in the Canadian context, these have enjoyed broad popularity in social movement activities with food workers elsewhere, such as in the USA and Brazil. In order to apply these cultural experiments to the Canadian setting, in this article I engage with the conceptual understanding of the SAWP as a guest-worker regime sustained by the incorporation of a state-sanctioned system of 'unfree labour'. Borrowing from the work of feminist philosopher Nancy Fraser, I further argue that the material injustices of unfree labour policies and the cultural narratives that support them profoundly restrict the communicative capacities of SAWP workers, greatly reducing these workers' ability to participate directly in food justice organizing. As a way of addressing the political and cultural 'misrecognition' of Canada's SAWP workers, I argue in this article that critical adult educators and food justice advocates should consider alternative, and in particular artistic approaches to grassroots organizing as a way to more effectively incorporate the voices of migrant farm workers in social movement. 
The article begins with an examination of farm worker agency in the context of Canada's SAWP. As an entry point, I begin with recent discussions within the food sovereignty scholarship that speak to the need for movement activists and scholars to address the social justice concerns of food labourers. Next, I discuss how the underlying logic of unfree labour relations permeates workers' experiences of daily life in Canada's SAWP. In the following section I examine how the notion of 'parity of participation', a conception of justice developed by feminist critical theorist Nancy Fraser, can help to formulate an approach to organizing SAWP workers that recognizes the need to foster not only the material, but also the cultural resources required to nurture workers' contribution to the food justice movement. I follow this section with an in-depth exploration of the context and results of a theatre-based adult education intervention with a group of SAWP workers employed in Canada's hydroponic greenhouse industry. The article ends with a brief discussion of how arts-based interventions such as the one I describe here can provide an ethical and effective means for workers to contribute to public conversations concerning migrant and food justice.

\section{Farm worker agency in Canada and the logic of unfreedom}

In the past decade there has been a growing interest among food justice scholars regarding a perceived disconnect between the food sovereignty movement and social justice concerns related to the exploitation of food labourers (Allen 2008). With notable exceptions (Gottlieb and Joshi 2010; Gray 2014) it is widely recognized that food movement scholarship has not been actively engaged with challenges facing food workers, particularly those who work in agriculture (Levkoe et al. 2016; Minkoff-Zern 2014; Sachs et al. 2014). While recent scholarship has examined the dynamics of unpaid labour on organic farms (Levkoe 2017; Ekers et al. 2016), a wider concern regarding the exploitation of paid farm employees in the context of industrial agriculture remains uncharted (Sachs et al. 2014). This discrepancy has been expressed most succinctly by Minkoff-Zern (2014, p. 86), who claims that "despite the popular attention given to food's provenance, the actual workers who pick and pack our food are consistently overlooked.” Similarly, Weiler and colleagues (Weiler et al. 2016) address this tension within the food movement in the Canadian context. Like scholars elsewhere, they claim that hired farm workers are absent from discussions of how to create sustainable food systems. They state that "supporters of these movements have been disengaged, in conflict with, or unsupportive of farmworker equity" (Weiler et al. 2016, p. 2). These various scholars point out how farmworker agency in particular has been either sidelined or not considered, bringing into sharp relief the question, raised by Feagan (2007, p. 29) of "who is in and who is out" when considering the idea of 'local' in food movement activism and knowledge production.

By sidelining the importance of farm worker agency, those involved in the food justice movement are missing an opportunity to understand how workers' interests could potentially shape the negotiation of production politics in agriculture. Concerned scholars call on food researchers to engage in forms of public sociology that support a movement toward social justice for food workers. Allen (2008, p. 160), for example suggests that investigators design "participatory, problem-solving research" that engages real people in 
their real lives. Similarly Kohl-Arenas and colleagues (Kohl-Arenas et al. 2014, p. 20) make the claim that the enduring inequalities embedded in agricultural work can only be addressed once "the voices and actions of those directly affected are included in the process of designing solutions to the problems they experience.” That notwithstanding, for those scholars who have addressed this shortcoming, there is agreement that while it may be imperative to do so, creating spaces for farm workers to participate in political dialogue is "tremendously difficult" (Weiler et al. 2016, p. 12).

The difficulty that Weiler and colleagues (Weiler et al. 2016) observe is associated with engaging farm workers in the wider food justice movement has contours that are particular to Canada. While recent scholarship is beginning to connect the struggles of farm workers in Canada to the sustainable food movement (Hjalmarson et al. 2015; Weiler et al. 2016) the issue of agricultural labour in this context has been most widely discussed in the area of migration and labour studies (Basok 2002; Preibisch 2010; Satzewich 1991). The primary focus of this work has been related to social, political, and economic examinations of Canada's Seasonal Agricultural Worker Program (SAWP), a bilateral state-managed 'guest worker' agreement between Canada, Mexico, and several Caribbean countries. A useful conceptual tool that has been employed in the service of interpreting the role that this state managed labour migration schema plays in Canada's horticultural industry is the notion of 'unfree labour' (Choudry and Smith 2016b; Sharma 2012; Thomas 2016). The condition of 'unfree labour' associated with the employment of migrant farm workers in Canada refers to the use of "extraeconomic compulsion... to exact labour power" (Choudry and Smith 2016a, p. 8) from workers, primarily through a restrictive migratory status (Perry 2012b; Satzewich 1991; Sharma 2006).

As a central mechanism of labour control and coercion, migrant farm workers' citizenship restrictions in Canada facilitate various techniques that constrict labour freedoms for workers in both the realms of circulation and production (Lebaron 2015; Preibisch 2010). These include: employer-specific work permits that limit workers' labour mobility; the requirement that workers reside on employer property; the nonauthorization of family unification; the requirement that workers return to their home countries at the end of their contracts; and wide-scale restrictions on social and political rights that constrain workers' access to social programs such as employment insurance and English as a Second Language instruction (Basok 2002; Nakache and Kinoshita 2010; Ramsaroop 2016). These policies produce an everyday home/workplace environment in which disciplinary employment practices may thrive, not the least of which are the constant threat of deportation and potential removal from the program as reprisal for resistant or defiant behaviours, including engaging in political activism (Basok et al. 2014; Vosko 2016). While these conditions severely limit the political options available to workers, it is well documented how this state mediated production of unfree labour relations and the incorporation of a trans-migrant labour force have benefited capitalist accumulation in Canadian agriculture since the SAWP's inception in 1966 (Preibisch 2010, 2012). As such, by fashioning workers into "disposable commodities" (De Genova 2005, p. 8) the policies and practices of unfreedom are crucial to production relations in Canada's agri-food sector, making workers' public participation particularly challenging. 
Scholars have generally incorporated a political economy approach to examining the production and reproduction of a system of 'unfree labour' in Canada's horticultural industry. Preibisch (2010) for example places an examination of unfree labour in agriculture within a wider context of a liberalized global food economy. She examines how the making of 'unfreedom' is a crucial means by which agricultural businesses can exact greater control over their workers in ways that benefit production. Still other scholars have examined how territorial borders play a key role in "securing and reproducing low wage and 'unfree' labour” (Thomas 2016, p. 24). In this vein, Sharma (2012) examines how nationalist discourses justify the subordination of migrant workers through differential forms of incorporation, thereby containing workers as political subjects while they are simultaneously integrated into the labour market as workers. What these scholars reveal is how extra-economic factors related to restrictive citizenship controls and nationalist discourses are used to extract labour power and pacify workers in the service of capitalist accumulation in Canada's agri-food sector. The result is the production of an agricultural workforce that is more likely to be compliant and less able to resist precarious working and living conditions.

That said, while the structure of unfree labour produces an insidious everyday discipline, there is a need for food movement activists and scholars to recognize that the agency of migrant farm workers is always present, at the very least as an ontological fact (Foucault 1980). Central to the question of worker agency and political subjectivity is how the logic of unfreedom described above influences how workers come to experience everyday life in Canada (Reid-Musson 2017). As Choudry and Smith (2016a, p. 12) observe, the immigration and employment controls that structure the SAWP are "enforced at the level of everyday social life and on the human body." This observation conjures a reading of unfree labour whereby the political and economic structures that produce an unfree condition of work seep into the private and non-work experiences of workers' daily lives (Rogaly 2009; Skrivankova 2010; Strauss 2012). This seepage exposes micro-layers of unfreedom that disturb "workers' control over their own bodies, movement, privacy and social life” (Lebaron 2015, p. 9). The condition of unfreedom to which migrant farm workers in Canada are subject can thus be viewed as a continuum of exploitation that far “exceeds the effects of a political or economic strategy" and profoundly affects workers' private and public lives, their relationships to each other, and the formation of social and cultural identities (De Lissovoy 2015, p. 63).

Research has shown how the logic of unfreedom that underlies workers' social isolation, cultural exclusion, and a lack of access to labour and mobility rights is legitimized through a public discourse that portrays workers as cultural and economic others (Bauder 2008). This is compounded by workers' embodied experiences of racialization in the rural, primarily agricultural, and majority White communities in which they live (Perry, 2012b). In other words, underlying the very logic of the program is an order of embodied distribution that classifies SAWP workers as racialized others within what Bakan (2008, p. 5) refers to as "a racialized culture of hegemonic whiteness." Culturally, the logic of unfreedom percolates beneath the surface of workers' relationships, structuring their experiences through a condition of otherness and invisibility, demanding that workers 
behave like workers. More than just producing a 'reliable' workforce, this underlying logic of subjection communicates the expectation that SAWP workers are "to stay in line and make [themselves] scarce” both inside and outside the workplace (Fanon 2008, p. 94). This produces a hyper-awareness of their surroundings and of their explicit and limited role in Canadian society, thus reifying workers' otherness, shaping their sense of agency, and stifling workers' ability to communicate dissent, both in private and in public.

Recognizing the socio-cultural effects of unfreedom and the necessity to cultivate worker agency are crucial to the development of critical educational interventions. This means developing creative strategies to address the material and cultural obstacles to workers' speaking out about farm worker equity. There is a tremendous need to develop healing and democratic spaces where SAWP workers can experiment with and perform ways of being that belie the underlying logic of unfreedom. Food movement activists can seek out insights and processes from critical pedagogy as a way to harness worker agency and to spark political subjectivities that disrupt the "dominative decorum" that permeates workers' everyday experience of Canada’s SAWP (De Lissovoy 2016, p. 346). Currently, there is a growing interest in the application of critical pedagogical methods among food movement activists and scholars. For example, Minkoff-Zern (2014) describes how cultural and educational activities are crucial aspects of developing leadership and solidarity among farm workers themselves.

\section{Leveraging cultural activities to encourage communicative parity}

How can cultural and educational interventions as suggested by Minkoff-Zern (2014) address the uneven politics of unfree labour as characterized above? The concept of 'misrecognition' as advanced by feminist political theorist Nancy Fraser $(1997,2013)$ can assist in developing these connections. Fraser describes misrecognition as "the material construction, through the institutionalization of cultural norms, of a class of devalued persons who are impeded from participatory parity” (Fraser 2013, p. 180). For Fraser, misrecognition takes place when social and political institutions regulate a particular group's interactions according to cultural and political norms that "constitute one as comparatively unworthy of respect or esteem” (Fraser 2013, p. 176), thus denying particular categories of people the opportunity to interact with one another as equals. The denial of equitable and unrestrained communication in the public realm to certain groups of people is thus understood as a key element of social injustice. Engaging with Fraser's concept of misrecognition highlights the importance of addressing the problem of voice when attending to farm worker equity in social movement contexts.

In Canada, there are material and ideological factors that impede migrant farm workers from full social and political membership. These contribute to the misrecognition of SAWP workers, and by extension to the scarcity of worker involvement in food justice initiatives. In particular, the disciplinary mechanism of unfree labour as produced through Canada's SAWP ensures that workers are unable to permanently settle in Canada. Workers are instead attached to a single employer throughout the duration of their contracts. These material restrictions limit workers' labour and geographic mobility, 
increase workers' risks of experiencing labour standards abuses, and also limit workers' ability to actively contribute to formal and grassroots debates that may potentially influence public policy. The cultural narratives that render SAWP workers as outsiders support these institutional relations, thus legitimating the permanent alienation of SAWP workers from having their voices heard in social and political forums. The dynamics of unfree labour, in tandem with the ideological discourses that legitimize them, thus produce a "vicious circle of cultural and economic subordination" (Fraser 1997, p. 15) that codes the patterns shaping the range of communicative possibilities available to SAWP workers in their everyday relationships. The issue of paid farm hands' absence from Canada's food movement is thus not just a problem of advocates' lack of access to workers, but is also a consequence of the deeper problem of workers' material and cultural exclusion from social and political life.

In response to the problem of misrecognition, Fraser posits a conception of justice that is grounded in the principle of "parity of participation", which "requires social arrangements that permit all (adult) members of society to interact with one another as peers" (Fraser 2013, p. 164). In order to increase the contribution of farm workers in social movement, migrant and food justice initiatives would do well to incorporate activities that encourage the type of communicative parity imagined by Fraser. This means developing educational environments that address the underlying cultural values that serve to justify the broad denial of workers from the rights and protections of full citizenship. In keeping with Fraser's notion of parity of participation, this must include creating spaces where migrant farm workers can come together to challenge the injuries suffered as a consequence of their pervasive exclusion from public life. Canada's food movement must develop creative opportunities for workers to contest cultural values that reify migrant farm worker subordination as the norm.

Cultural and creative activities are not unusual in social movement organizing. On the contrary, interweaving community organizing with artistic practices, such as collective storytelling (Newman 2006) and performance (Hsia 2010), is increasingly common as a potentially effective grassroots approach to strengthening the communicative potential of people from traditionally marginalized groups. Within the field of critical adult education in particular, the arts have been proposed as an important vehicle to cultivate and communicate counter-hegemonic ideas and to develop relationships of solidarity and connection in social movement contexts (Butterwick and Roy 2016; Brookfield and Holst 2010; Choudry 2015). Notably, migrant and food justice movements alike have mobilized artistic forms of "cultural organizing" to claim public space and to honour both farm workers and transnational migrants in various international settings as "creative and purposeful human beings” (Kohl-Arenas et al. 2014, p. 12). Both the Landless Farm Worker Movement in Brazil and Florida's Coalition for Immokalee Workers for example have incorporated storytelling, music, and theatricality as a way to build solidarity and forge common identity among agricultural workers and the general public (Gouge 2015; Hammond 2014; Issa 2007). Other examples, such as those that have incorporated artistic exploration with transnational marriage migrants in Taiwan (Hsia, 2010; Liang, 2016) and Filipina live-in caregivers in Canada (Butterwick et al. 2015), have integrated performance as a way to create a space where communal migrant subjectivities may be 
cultivated. As seen through the lens of Nancy Fraser's conceptualization of justice, these examples highlight how collective artistic creation can leverage often-untapped cultural resources to address the problem of misrecognition and to support parity of participation among traditionally marginalized communities. How can cultural activities be mobilized with hired farm hands who are affected by unfree labour policies, such as SAWP workers in the context of Canada's horticultural industry? In what follows I discuss the trajectory and results of my own efforts to carve out a space where SAWP workers are encouraged to contribute their voice to migrant and food justice activism through cultural and artistic expression.

\section{Engaging migrant farm workers in community-based arts}

The reflection offered in this article is grounded in my 15 years of experience as an adult educator, advocate, and later, as a university-based researcher working with SAWP workers. My work with migrant workers began with my position as a labourer-teacher with Frontier College, a well-established literacy organization in Canada. In this position I worked as both a farmworker and as a volunteer English as a Second Language and literacy instructor. In order to sustain my volunteer work, for three years I worked and lived alongside migrant farm workers on tobacco and fruit farms in the agriculture-rich region of Southwestern Ontario. My proximity to workers as a fellow co-worker greatly informed my work as an advocate and as an educator (Perry 2013). During these years I spent my evenings and weekends delivering student-centred language lessons to interested co-workers and their friends. Lessons were focused on fulfilling workers' daily communication needs in the local language, providing a practical foundation for encouraging worker independence.

After two years as a language instructor, I was approached by a group of advanced language learners in the municipality of Leamington (pop. 27,595), a crucial hub for Canada's greenhouse industry. In 2015 (the most recent numbers available) Leamington was host to 5,743 migrant workers, the vast majority employed in the agri-food industry (Government of Canada 2018). This group of workers wanted my help to write and perform a collaboratively created play about their lives as migrant farm workers in Canada. This group made it clear that they wanted to perform in English, and that their intended audience would be local Canadians. Feeling socially and culturally isolated in the town where they lived, the group's goal was to employ a creative outlet to educate locals about their daily lives. Over the course of a summer, this group of workers met twice a week after work, often commuting long distances to town by bicycle, to create and rehearse a short play that was eventually performed for a mixed audience of SAWP workers and local Canadians at a community centre. While this project provided a means for workers to express themselves creatively, workers' decision to target an audience that included non-migrant workers introduced a pedagogical limitation. Namely, with a Canadian audience in mind, this group decided to develop and publically share a story about life as a migrant worker that purposefully did not challenge the accepted status quo, so as to avoid the known social risks associated with workers publicly expressing themselves as political subjects. With the worry that SAWP employers may be present in the audience (and some were), the group chose not to document workers' real-life 
struggles and instead crafted a light-hearted love story, thus portraying the SAWP as benign and workers themselves as gentle and fun-loving neighbours.

The experience of leading this project was both invigorating and frustrating. On the one hand, having the chance to help workers to shape and share their own stories in a public forum was energizing. On the other hand, being constrained with regards to the types of stories we could share as a group felt like a missed opportunity. While the production of this play was considered an important and distinctive cultural performance that communed a rich emotional depiction of life in Canada's SAWP (Hill 2005), it did not embrace an explicit analysis of how relations of dominance imbue workers' experiences of work and migration. Could a cultural activity such as the one proposed by this group of SAWP workers not be a potentially effective approach to public and political pedagogy, and contribute in some way to established migrant and food justice movements? To the contrary, this project was illustrative of the challenges associated with the cultural and material obstacles to inviting SAWP workers to contribute their voices to political struggle. While artistic activities associated with critical adult education may offer a means of encouraging workers to express a collective subjectivity (Brookfield and Holst 2010; Hsia 2010; Newman 2006), in this case the risks associated with public displays of communal agency suppressed even the perception that workers were reflecting on and critiquing dominant social relations. Several years later, as a university-based researcher, I decided to try this play-making experiment a second time with a different group of workers. With an eye to liberating workers from the gaze of employers and the wider Canadian population, this second project was designed from the outset to be by and for workers themselves. Given the results of the previous play-making experiment, I felt that workers interested in cultural production needed a private workeronly space to experiment - a place that was free from outside scrutiny (see Flores and Garcia 2009). The idea was to create a space where workers could bear communal witness to life in the SAWP and where workers' experiential knowledge of unfree labour could be nurtured. A crucial question animating this decision was related to how an SAWP worker-only arts-collective could provoke a grass-roots cultural interchange that could address the problem of misrecognition as it is expressed through Canada's managed labour migration system.

\section{A note on methods}

I base the analysis presented in this article on a series of theatre workshops conducted with a group of SAWP workers from Mexico working in Canada's hydroponic greenhouse industry. Methodologically, this project was committed to both emphasizing the agency of participants and to producing social science research that does not simply document the social world, but which is active in its very production (Denzin 2003; Law and Urry 2004). On both of these fronts, a performative approach to qualitative inquiry offered a rich and provocative invitation toward engaging with farm workers. To better understand how the application of arts-based workshops can be harnessed in food movement activism, this article focuses on cooperative meaning making and solidarity learning as these occurred during the workshops themselves and the performance that followed. 
The theatre-creation workshop sessions were developed from well-established community-based approaches to collective theatre creation, primarily the Theatre of the Oppressed, a social justice-oriented theatrical technique developed specifically for use with non-actors by the late Brazilian theatre director and educator Augusto Boal (1985, 2002). Among activists and arts educators, Boal's Theatre of the Oppressed is often portrayed as an artistic technique for critically examining hegemonic social relations with and among traditionally marginalized groups (Barak 2016; Hsia 2010). As per the process of Boal's work, our sessions involved the group coming together to examine their everyday lives through physical movement exercises, theatrical improvisations, in-depth discussions, storytelling, collective play creation, and community-based performance. The project incorporated three distinct phases: embodied inquiry, play-creation, and public performance (Perry 2018). The first phase was grounded in Boal's technique of 'image theatre' (Boal 2002, pp. 139-147). In this phase workers created static body images of their lives in the SAWP. By working in mostly silence and focusing primarily on workers' bodies, this phase was designed to emphasize workers' non-verbal resources, including emotions, memories, and workers' perceptions of embodied interactions with others. Intended to spark collective memories and new interpretations of life in the SAWP, these images became a catalyst for group discussions in which workers shared and compared their own personal life histories (Perry 2012a). This phase was followed by the creation of a short play. The collectively created play was based on the images that were generated in the previous phase and the discussions that followed. Using a patchwork of methods derived from Boal's toolbox, such as collective improvisation and character development, participants constructed a series of dramatic scenes that examined the challenges associated with a worker's first year in the program.

An integral aspect of this project was to provide adequate space for workers themselves to collectively improvise their own representations of daily life as migrant farm workers. In the interests of respecting workers' own interpretations of life in Canada's SAWP, participants were therefore fully engaged in all aspects of developing artistic depictions (Sinding et al. 2008). This meant that all participants were involved in artistic creation and that all of the images, characters, dialogue, and scenes that workers created were fully examined in relation to each individual worker's lived experiences, worldviews, and personal beliefs. All of the voices present were therefore urged to partake in a conversation of how to best portray the intimate realities of life for participants. In practical terms, this meant encouraging participants to pause the workshop activities at any time in order to discuss in more detail the topic at hand. The process of engaging with a multiplicity of worker voices deepened the ethical grounding of the project and strengthened the accuracy of artistic representations prior to public scrutiny

(Conquergood 1985; Mienczakowski 1999). Unlike the previous play that was created for a mixed audience of workers and Canadians, the play that participants created expressly probed some difficult material, such as uneven power relations in the workplace, coworker harassment, problematic interactions with program officials, and loneliness. After the play was created and rehearsed, we invited an audience of 25 fellow workers to attend the final performance. The presentation was designed as a community forum. This involved incorporating a facilitated discussion meant to elicit the audiences' responses to 
both the content covered in the play as well as the experience of being involved in a worker-led dialogue on their lives in the SAWP.

In an effort to access workers most obviously denied the status as 'peer' as per Fraser's conceptualization of misrecognition, my goal was to enlist workers who were not already involved in community organizing. The rationale was to encourage workers who did not already have the experience of expressing themselves in a public and overtly political way to experiment with the development of a communal voice. While I was no longer volunteering as a language instructor at the time, I was given permission by Frontier College to attend several of their Leamington classes in order to pitch my idea to potential participants. In these presentations I told workers about my own experiences as a farmworker and volunteer advocate, and told them about the previous theatre-making project. I informed workers that the point of the current project was to bring workers together to build community and to create and share stories amongst themselves that were relevant to their true-to-life struggles as migrant farm workers in Canada. I explained that the project would be limited to workers only, and that no members of the local community would be involved in either the workshops or the public performance. In this way, I was able to offer workers an assurance of relative confidentiality.

Interested workers were also made aware that this endeavour was associated with a university-based research project that examined the efficacy of artistic interventions to create meaningful stories that support worker solidarity and parity of participation. On this front, I asked workers' permission to observe their interactions during the theatrecreation workshops and to include their anonymized exchanges in future reports and publications. Audience members (who were also SAWP workers) were similarly informed of the research dimension of the project, and were likewise asked for their consent to participate. In the end, I enlisted a group of nine SAWP workers from Mexico to contribute to a theatre creation and performance project that lasted throughout a complete agricultural season. The workers who were most eager to take part in this project were individuals who had expressed a desire to develop social connections outside of work through involvement in activities separate from their working lives. For these amateur worker-artists, our weekly workshops were both an opportunity to socialize with like-minded workers and a means to express parts of their identities that normally lie dormant throughout their sojourns in Canada. Those workers who stated their motivation for participating in the project discussed how they found meaning in creating art that mirrored their own experiences and those of their fellow SAWP workers. One worker (Joaquín) ${ }^{1}$ expressed this sentiment thus:

The project is important because the play expresses the situations that we are living as migrant workers. ${ }^{2}$

For these workers having the chance to express themselves artistically was especially appealing. In the words of one worker (Enrique):

${ }^{1}$ I provided workshop participants with pseudonyms.

${ }^{2}$ Worker quotes have been translated to English from the original Spanish. 
I liked the idea of being in a play about Mexicans. I always wanted to participate in something like this. Well, when you invited me it got me really excited.

Drawing from my own observations of participant interactions during this project, in what follows I offer a glimpse of how artistic educational interventions with migrant farm workers may be one way to incorporate the voices of food labourers into migrant and food justice movements. By focusing most of the analysis on the first, 'image theatre' phase of this project, I examine how simple theatrical explorations can offer a unique means of accessing workers' embodied experiences of work, unfree labour, and social struggle. I reveal how a thoughtful exploration of workers' experiential knowledge of life in Canada's SAWP can facilitate critical collective discussions of how power infiltrates workers' everyday lives. The discussion below demonstrates how in-depth investigations of the memories and emotions that undergird workers' experiences of manual agricultural labour produced an opportunity to augment participants' capacity to communicate a collectively produced reflection on worker camaraderie, worker agency and the logic of unfree labour.

\section{Images of work, images of defiance}

Work

You have to live what we live in your own body to know what we feel. The play more than anything provides a reflection on what it is we are living through here in Canada as workers... on what we are really living through.

An (anonymous) SAWP worker expressed this provocative statement during the postperformance discussion at the end of the arts project described in this article. This quote demonstrates the importance of engaging with farm workers' experiential knowledge of life in Canada's SAWP as a way of learning about the lived realities of unfree labour relations. For critical adult educators, finding a way to encourage workers to physically interrogate the social relations that shape their daily lives is crucial to incorporating the voices of SAWP workers in food movement activism, as is suggested in the literature reviewed above. In keeping with this goal, the first phase of this project involved facilitating 'image theatre' exercises with the group. Practitioners of the Theatre of the Oppressed describe the technique of image theatre as "a series of wordless exercises in which participants create embodiments of their feelings and experiences" (Schutzman and Cohen-Cruz 1994, p. 237). Given this technique’s emphasis on accessing memories, emotions and other physical experiences that may be difficult to articulate clearly in spoken language, I chose image theatre specifically because of its potential to engage workers' tacit and embodied knowledge of everyday life (Perry 2018).

During the first few sessions, an explicit focus on embodied knowledge did not immediately produce in-depth explorations of what could be characterized as workers' experiential knowledge of unfree labour relations. Rather, when workers were offered the chance to use their bodies to communicate information about their lives in the SAWP, 
they instinctively created images that depicted the simple everyday actions and situations associated with physical agricultural labour. For example, during the early stages of the project, workers created images of picking tomatoes, tying the vines of tomato plants, and of manipulating complex greenhouse machinery. This was not surprising, seeing as though SAWP labourers often work upwards of 60-hour weeks and are drawn from the ranks of racialized global labouring classes (Basok 2002; Smith 2016). These are workers for whom rich and varied experiences of manual labour are deeply embedded in their embodied understandings of daily life. SAWP workers' day-to-day activities at work were therefore easily recreated through theatrical image making. In the words of one project participant (Mauricio):

We do these activities all day everyday. These actions are impossible to forget.

These images offered more than just a surface-level representation of participants' working lives, however. By coming together on a weekly basis to engage in an artistic exploration workers developed affective camaraderie grounded in their own intimate experiences of agricultural work, which provided an effective means of developing a communal subjectivity. For example, during the workshops participants discussed openly how creating theatrical images of work sparked individual memories of their lives in the program that merged with the collective memory of the group. This was particularly true for one worker (Enrique), who was in his first year in the program at the time of research and was particularly struck by how the experiences of older workers mirrored his own. Reflecting on an image created by one of his more senior co-workers that depicted his employer yelling at him on his first day of work, Enrique commented:

I remembered when I first came into the program. Joaquín's story was almost exactly the same as what happened to me.

Connecting the individual memory of work to the collective memory of exploitation may thus have supported the development of a communal understanding of the SAWP experience. The workshops thereby provided a space for workers to develop a shared sense of responsibility and care, thus triggering an important interruption of workers' everyday experiences of social exclusion and isolation. For example, during these initial theatre workshops it was not unusual for older workers to stop the action in order to provide council to younger workers on how to develop practical strategies to protect their bodies from long-term injuries. This collective interrogation of how life in the SAWP could be represented through a commonly understood physical vernacular provided a central foundation for surfacing workers' embodied knowledge of broader social relations.

\section{Defiance}

In an effort to deepen the analysis, these embodied images of work were "brought to life" through interactive exercises known to Theatre of the Oppressed practitioners as 'dynamizing' activities (Schutzman and Cohen-Cruz 1994, p. 237). With varying degrees of success, and using assorted improvisational tools, I encouraged participants to reflect 
on the internal and external forces that animated the collectively created physical images of agricultural labour. For example, during this phase participants improvised the development of different characters, such as SAWP employers, government officials, spouses, and fellow workers. These improvisations presented a window to interrogating the underlying emotions, motivations, and political interests that determine workers' everyday experiences of work. In one activity that proved particularly fruitful, in the process of demonstrating previously created images of greenhouse work, I asked participants to express their character's 'inner monologues' (Boal 2002, p. 207). In this exercise, participants voiced the inner thoughts of the characters (i.e. workers, employers, consular officials) involved in the images of work that they had already created. These otherwise innocuous images of agricultural labour were thus transformed. From these images participants created polyphonic soundscapes that evoked a potent account of how power, as filtered through the policies and practices of unfree labour, shapes the embodied everyday experience of life in Canada's SAWP. As an example, the following internal monologues developed from an image of greenhouse work are illustrative. One participant, who was playing the part of an employer, voiced his complaints about his Mexican employees working too slowly and decided that he would threaten to send them back to Mexico in order to make them work faster. Another participant, who was playing a worker in his first SAWP season, extracted a litany of profane language thrown in the direction of his employer, who he felt was treating him unfairly. The next participant, playing the part of a worker, spoke to his spouse about how much he missed her, and that he hoped working in Canada would provide financial opportunities for their family. A fourth participant, also playing the role of a worker, expressed his fear that the employer would punish him and his fellow co-workers because one member of his crew was working too slowly. Voicing the private concerns of fictional (but true-to-life) SAWP characters that they themselves created encouraged participants to critically examine how the policies and practices of unfree labour may infiltrate workers' bodies and structure their everyday relationships.

Unlike earlier discussions that focused primarily on building workers' long-term physical resilience to the bodily hardships associated with farm work, these moments provoked conversations in which workers shared and compared memories of unjust treatment and debated the risks associated with speaking out. These discussions in turn provided the groundwork for developing embodied images of defiance that could then be incorporated into migrant and food justice organizing. To illustrate: at the time this phase of the project was taking place, the volunteer-led migrant justice collective, Justicia for Migrant Workers was organizing a campaign called the 'Pilgrimage to Freedom', a summer-long action which involved grassroots activists and migrant farm workers staging events across the province of Ontario. Event organizers invited interested workers from our group to join a small group of worker-activists to create dramatic images that could be incorporated into the caravan's communications strategy, such as campaign posters and banners. This invitation provided a means for this group of artist-workers to contribute to public and political pedagogy while at the same time maintaining their anonymity. Prior to this gathering, I invited workers to bring objects that for them represented different aspects of their lives in Canada. On the day of the workshop we had a motley collection of farm-related objects, including various small agricultural tools as well as an assortment 
of tomatoes and cucumbers. Using these objects as props, throughout the day, this blended group of workers collectively created images meant to represent both the realities of workers' lives and the broader struggle for farm worker equity.

By the end of this session, the collective of workers had settled on one particular image that we felt captured workers' experiential knowledge of manual work, unfree labour, and social struggle. <<Fig. 1 about here $>>$ In the image (Fig. 1 Image of Defiance), a hand holding a tomato represents manual work, a chain wrapped around the worker's hand and arm symbolizes unfree labour, and a fist raised in defiance embodies the idea of social struggle. This image was transformed into a digital image that was later attached to Justicia for Migrant Workers’s 2016 'Harvesting Freedom’ campaign (Justicia for Migrant Workers 2017), a Canada-wide migrant justice event that commemorated the 50year anniversary of Canada's SAWP (Fig. 22016 Harvesting Freedom Campaign Logo) (Justicia for Migrant Workers 2017). <<Fig. 2 about here $>>$ Depictions of manual labour were thus transformed into embodied images that contributed to on-the-ground migrant and food justice activism. This example demonstrates how a recognized arts-based educational practice can be taken up in the service of increasing the communicative capacity of migrant farm workers in the context of community organizing. The use of Augusto Boal's technique of image theatre was particularly useful in accessing workers' embodied knowledge of work, unfree labour, and social struggle. This technique, which focused on engaging workers' bodies in a collective investigation of life in Canada's SAWP, provided a creative means to spark not only a sense of affective camaraderie and communal subjectivity amongst workers not normally engaged in social movement, but also to provoke conversations that may otherwise not have taken place. Crucial to this approach is how arts workshops provided a grassroots mechanism for cooperatively examining some of the most salient and richest material available for engaging workers in struggles for justice, namely workers’ own direct experiences of physical labour.

A note on public performance

The eventual performance derived from the images described here provides further evidence as to the potential and the obstacles for community-based artistic practice to contribute to discussions of farm worker equity. This performance took place near the end of the agricultural season. Fellow SAWP workers who were in attendance were invited to participate in a discussion on the utility of artistic creation to communicate workers' impressions of life in the program. These workers' comments highlight how artistic expression can provoke strong feelings regarding workers' own perceptions of whether or not they are capable of or even entitled to expressing discontent. On the one hand, some workers expressed consternation on witnessing workers express oppositional subjectivities on the stage. The following anonymous audience comments reflect this position:

If we present this to the public, well, I don't know. Like what do you think? What would the Canadian government say? What would the Mexican consulate say? They might just grab you and ask 'who gave you the permission to have this idea?' 
We have a situation here, because Canadians will say, 'who let them do this'? The bosses will say, the Mexican consulate will say, the Mexican Ministry of Labour will say, 'who let them do this?' The bosses would not like to see this. They would send us all back to Mexico.

On the other hand, some workers felt as though play creation and performance could provide an effective way to increase workers' communicative capacity. The following comments reflect this position:

The play releases the burden that we all have, to let it go, to express it. It is a way to rebel against the situation that we are all living, because the other option is to just remain silent.

Do you have courage, or what? I have courage, and for me, I would perform this play in public because everything is shown - the good and the bad. Think about the consequences that this play could have. If people could start to see all these things, I don't know how far it would go, but it would create a real commotion.

Workers' performative subversion of the accepted norms of what it means to be a migrant farm worker in Canada through theatre creation sparked an emotional dialogue among those workers present in the audience. That audience members were so animated in their responses to the artistic expression of their fellow workers demonstrates how deeply enmeshed this project was in bringing to light the politics of worker representation in social struggle. While no clear resolution came out of this discussion, its very occurrence represents an incremental step toward participatory parity in the struggle to incorporate migrant farm worker voice into food justice organizing. Workers' collective exploration of manual agricultural work, as expressed through the artistic engagement of workers' actual bodies, presented an opportunity to aesthetically tap into workers' emotions, memories, and embodied experiences of unfree labour. This initiative offered a group of farm workers the time and space to reflect on their lives, and a relatively low-risk platform from which they could explore how they may want their voices heard within the contemporary food and migrant justice movements. Borrowing insights from Fraser (1997, 2013), this project provided a cultural platform for migrant farm workers to interact as peers in such a way that invokes the prospective of engaging with participatory parity in the migrant justice and food sovereignty movements.

\section{Conclusion}

Are there aspects of this small-scale community-based theatre project that address the problem, as articulated in the literature, of connecting the struggles of actual farm workers to the wider food justice movement? In the context of Canadian agri-business, this question must be framed in relation to the dynamics of unfree labour, and how these shape migrant farm workers' experiences of life in Canada's Seasonal Agricultural Worker Program. The notion of unfree labour that I examine in this article is gaining currency of late in the labour migration scholarship coming out of the Canadian context, and for good reason. Engaging with the idea of unfree labour provides a useful 
conceptual tool for understanding how restrictive citizenship controls and nationalist discourses are put to work in extracting labour control and pacifying workers in Canada's agricultural sector. In addition to restricting the political, geographic and labour mobility of SAWP workers, the logic of unfreedom that undergirds the structure of transnational agricultural employment in Canada is an insidious form of everyday discipline. The politics of unfree labour that variously constrain SAWP workers' opportunities to participate as full community members through mechanisms such as the constant threat of deportation, are thus sutured to workers' embodied experiences of daily life. I thereby introduce the concept of misrecognition as posited by Nancy Fraser as a way to further deepen our understanding of how the cultural and economic politics of unfree labour infiltrate SAWP workers' everyday relationships. By inspecting Canada's SAWP through the lens of misrecognition, I make the case that the politics of unfree labour produce communicative constraints for farm workers that profoundly affect their opportunities to interact as equals in Canadian society. This presents a grave problem for Canadian food justice advocates who are interested in engaging farm workers in public conversations around farmworker equity and food sovereignty. However, in this article I argue that Canada's migrant and food justice advocates must address the lack of communicative resources available to SAWP workers in order to address problems related to the exploitation of food labourers. Educational interventions designed to encourage migrant farm workers' contribution to social movements must therefore tackle the socio-cultural obstacles that constrict migrant farm workers' opportunities to participate as full members of their communities. When designed thoughtfully, social justice oriented approaches to community-based arts can provide one way of accomplishing this objective.

All procedures performed in studies involving human participants were in accordance with the ethical standards of the University of Toronto and with the 1964 Helsinki declaration and its later amendments or comparable ethical standards. Informed consent was obtained from all individual participants included in the study.

\section{References}

Allen, P. 2008. Mining for justice in the food system: Perceptions, practices, and possibilities. Agriculture and Human Values 25(2): 157-161.

Bakan, A. B. 2008. Reconsidering the underground railroad: Slavery and racialization in the making of the Canadian state. Socialist Studies 4(1): 3-29.

Barak, A. 2016. Critical consciousness in critical social work: Learning from the Theatre of the Oppressed. British Journal of Social Work 6(1): 1776-1792.

Basok, T. 2002. Tortillas and tomatoes: transmigrant Mexican harvesters in Canada. Montreal, QC: McGill-Queen’s University Press.

Basok, T., D. Bélanger, and E. Rivas. 2014. Reproducing deportability: Migrant agricultural workers in South-western Ontario. Journal of Ethnic and Migration Studies 
40(9): 1394-1413.

Bauder, H. 2008. Foreign farm workers in Ontario (Canada): Exclusionary discourse in the newsprint media. Journal of Peasant Studies 35(1): 100-118.

Boal, A. 1985. Theatre of the oppressed. New York, NY: Theatre Communications Group.

Boal, A. 2002. Games for actors and non-actors. London, UK: Routledge.

Brookfield, S., and J. Holst. 2010. Radicalizing learning: Adult education for a just world. San Francisco, CA: Jossey-Bass.

Butterwick, S., M. Carrillo, and K. Villagente. 2015. Women's fashion shows as feminist transformation. The Canadian Journal for the Study of Adult Education 27(2): 79-99.

Butterwick, S., and C. Roy. 2016. Working the margins of community-based adult learning. New York, NY: Springer.

Choudry, A. 2015. Learning activism: The intellectual life of contemporary social movements. Toronto, ON: University of Toronto Press.

Choudry, A., and A. Smith. 2016a. Introduction: Struggling against unfree labour. In Unfree labour? Struggles of migrant and immigrant workers in Canada, ed. A. Choudry, and A. Smith, 1-20. Oakland, CA: PM Press.

Choudry, A., and A. Smith, eds. 2016b. Unfree labour? Struggles of migrant and immigrant workers in Canada. Oakland, CA: PM Press.

Conquergood, D. 1985. Performance as moral act: Ethical dimensions of ethnography of performance. Literature in Performance 5(2): 1-13.

De Genova, N. 2005. Working the boundaries: Race, space, and "illegality" in Mexican Chicago. Durham, NC: Duke University Press.

De Lissovoy, N. 2015. Education and emancipation in the neoliberal era: Being, teaching, and power. New York, NY: Palgrave Macmillan.

De Lissovoy, N. 2016. Race, reason and reasonableness: Toward an "unreasonable" pedagogy. Educational Studies 52(4): 346-362.

Denzin, N. K. 2003. Performance ethnography: Critical pedagogy and the politics of culture. Thousand Oaks, CA: Sage Publications.

Ekers, M., C. Z. Levkoe, S. Walker, and B. Dale. 2016. Will work for food: Agricultural interns, apprentices, volunteers, and the agrarian question. Agriculture and Human 
Values 33(3): 705-720.

Fanon, F. 2008. [1952]. Black skin, white masks. New York, NY: Grove Press.

Feagan, R. 2007. The place of food: Mapping out the "local" in local food systems. Progress in Human Geography 31(1): 23-42.

Flores, J., and S. Garcia. 2009. Latina testimonios: A reflexive, critical analysis of 'Latina space’ at a predominantly White campus. Race, Ethnicity and Education 12(2): 155-172.

Foucault, M. 1980. Power/knowledge: Selected interviews and other writings 1972-1977. New York, NY: Pantheon Books.

Fraser, N. 1997. Justice interruptus: Critical reflections on the 'postsocialist' condition. New York, NY: Routledge.

Fraser, N. 2013. Fortunes of feminism: From state-managed capitalism to neoliberal crisis. London, UK: Verso.

Gottlieb, R., and A. Joshi. 2010. Food Justice. Cambridge, UK: MIT Press.

Gouge, M. C. 2015. Human rights in play, transnational solidarity at work: Creative playfulness and subversive storytelling among the Coalition of Immokalee Workers. Critical Sociology 42(6): 861-875.

Government of Canada. 2018. Annual labour market impact assessment statistics 20082015 by urban area. https://www.canada.ca/en/employment-socialdevelopment/services/foreign-workers/reports/2014/Imia-annual-statistics/urbanarea.html. Accessed 10 March 2018.

Gray, M. 2014. Labor and the locavore: The making of a comprehensive food ethic. Berkeley, CA: University of California Press.

Hammond, J. L. 2014. Mística, meaning and popular education in the Brazilian Landless Workers Movement. Interface: A Journal for and about Social Movements 6(1): 372391.

Hill, S. 2005. Migrant workers take to stage. Windsor Star, 19 August.

Hjalmarson, E., R. Bunn, A. Cohen, E. Terbasket, and L. Gahman. 2015. Race, food, and borders: Situating migrant struggle in the Okanagan Valley, British Columbia. Journal of Agriculture, Food Systems, and Community Development 5(4): 77-82.

Hsia, Hsiao-Chuan. 2010. The subjectivation of marriage migrants in Taiwan: The insiders' perspectives. In Learning from the ground up: Global perspectives on social movements and knowledge production, ed. A. Choudry and D. Kapoor, 101-120. New 
York, NY: Palgrave Macmillan.

Issa, D. 2007. Praxis of empowerment: Mística and mobilization in Brazil's landless rural workers' movement. Latin American Perspectives 34(2): 124-138.

Justicia for Migrant Workers. 2017. Harvesting freedom. https://harvestingfreedom.org/. Accessed 24 Oct 2017.

Kohl-Arenas, E., M. M. Nateras, and J. Taylor. 2014. Cultural organizing as critical praxis: Tamejavi builds immigrant voice, belonging, and power. Journal of Poverty 18(1): 5-24.

Law, J. and J. Urry. 2004. Enacting the social. Economy and Society 33(3): 390-410.

Lebaron, G. 2015. Unfree labour beyond binaries: Insecurity, social hierarcy and labour market restructuring. International Feminist Journal of Politics 17(1): 1-19.

Levkoe, C. Z., N. McClintock, L.-A. Minkoff-Zern, A. K. Coplen, J. Gaddis, J. Lo, and A. M. Weiler. 2016. Forging links between food chain labor activists and academics. Journal of Agriculture, Food Systems, and Community Development 6(2): 129-142.

Levkoe. 2017. Engaging the tensions of ecological internships: Considerations for agroecology and sustainable food systems movements. Agroecology and Sustainable Food Systems. https://doi.org/10.1080/21683565.2017.1347120.

Liang, P. 2016. Interweaving ethics and aesthetics: Marriage migrants and theatre making in the Asian transnational space. Inter-Asia Cultural Studies 17(3): 334-356.

Mienczakowski, J. 1999. Ethnography in the hands of participants: Tools for dramatic discovery. In Explorations of methodology, ed. G. Walford and A. Massey, 145-161. Bingley, UK: Emerald Group Publishing Limited.

Minkoff-Zern, L.-A. 2014. Challenging the agrarian imaginary: Farmworker-led food movements and the potential for farm labor justice. Human Geography 7(1): 85-101.

Nakache, D., and P. J. Kinoshita. 2010. The Canadian temporary foreign worker program: Do short term economic needs prevail over human rights concerns? Montreal, QC: Institute for Research on Public Policy.

Newman, M. 2006. Teaching defiance: Stories and strategies for adult educators. San Francisco, CA: Jossey-Bass.

Perry, J. A. 2012a. A silent revolution: 'Image theatre' as a system of decolonization. Research in Drama Education: The Journal of Applied Theatre and Performance 17(1): 103-119. 
Perry, J. A. 2012b. Barely legal: Racism and migrant farm labour in the context of Canadian multiculturalism. Citizenship Studies 16(2): 189-201.

Perry, J. A. 2013. Living and learning through solidarity and struggle: Assessing the informal learning of Frontier College labourer-teachers. In Volunteer work, informal learning and social action, ed. F. Duguid, K. Mündel, and D. Schugurensky, 79-99. Rotterdam, NL: Sense Publishers.

Perry, J. A. 2018. Play-making with migrant farm workers in Ontario, Canada: A kinesthetic and embodied approach to qualitative research. Qualitative Research. https://doi.org/10.1177/1468794117743463.

Preibisch, K. 2010. Pick-your-own labor: Migrant workers and flexibility in Canadian agriculture. International Migration Review 44(2): 404-441.

Preibisch, K. 2012. Migrant workers and changing work-place regimes in contemporary agricultural production in Canada. International Journal of Sociology of Agriculture and Food 19(1): 62-82.

Ramsaroop, C. 2016. The case for unemployment insurance benefits for migrant agricultural workers in Canada. In Unfree labour? Struggles of migrant and immigrant workers in Canada, ed. A. Choudry and A. Smith, 105-122. Oakland: PM Press.

Reid-Musson, E. 2017. Intersectional rhythmanalysis: Power, rhythm, and everyday life. Progress in Human Geography. https://doi.org/10.1177/0309132517725069.

Rogaly, B. 2009. Spaces of work and everyday life: Labour geographies and the agency of unorganized temporary migrant workers. Geography Compass 3: 1975-1987.

Sachs, C., P. Allen, A. R. Terman, J. Hayden, and C. Hatcher. 2014. Front and back of the house: Socio-spatial inequalities in food work. Agriculture and Human Values 31(3): 3-17.

Satzewich, V. 1991. Racism and the incorporation of foreign labour: Farm labour migration to Canada since 1945. New York, NY: Routledge.

Schutzman, M., and J. Cohen-Cruz. (eds.). 1994. Playing Boal: Theatre, therapy, activism. New York, NY: Routledge.

Sharma, N. 2006. Home economics: Nationalism in the making of "migrant workers" in Canada. Toronto, ON: University of Toronto Press.

Sharma, N. 2012. The “difference” that borders make: “Temporary foreign workers” and the social organization of unfreedom in Canada. In Legislated inequality: Temporary labour migration in Canada, ed. P. T. Lenard and C. Straehle, 26-47. Montreal, QC: McGill-Queen’s University Press. 
Sinding, C., R. Gray, and J. Nisker. 2008. Ethical issues and issues of ethics. In Handbook of the arts in qualitative research, ed. J. G. Knowles and A. L. Cole, 459-468. Los Angeles, CA: Sage Publications.

Skrivankova, K. 2010. Between decent work and forced labour: Examining the continuum of exploitation. York, UK: Joseph Rowntree Foundation.

Smith, A. 2016. Migration, development and security within racialised global capitalism: Refusing the balance game. Third World Quarterly 37(11): 2119-2138.

Strauss, K. 2012. Coerced, forced and unfree labour: Geographies of exploitation in contemporary labour markets. Geography Compass 6(3): 137-148.

Thomas, M. 2016. Producing and contesting "unfree labour" through the Seasonal Agricultural Worker Program. In Unfree labour? Struggles of migrant and immigrant workers in Canada, ed. A. Choudry and A. Smith, 21-36. Oakland, CA: PM Press.

Vosko, L. F. 2016. Blacklisting as a modality of deportability: Mexico's response to circular migrant agricultural workers' pursuit of collective bargaining rights in British Columbia, Canada. Journal of Ethnic and Migration Studies 42(8): 1371-1387.

Weiler, A., C. Levkoe, and C. Young. 2016. Cultivating equitable ground: Communitybased participatory research to connect food movements with migrant farmworkers. Journal of Agriculture, Food Systems, and Community Development 6(2), 73-87. 


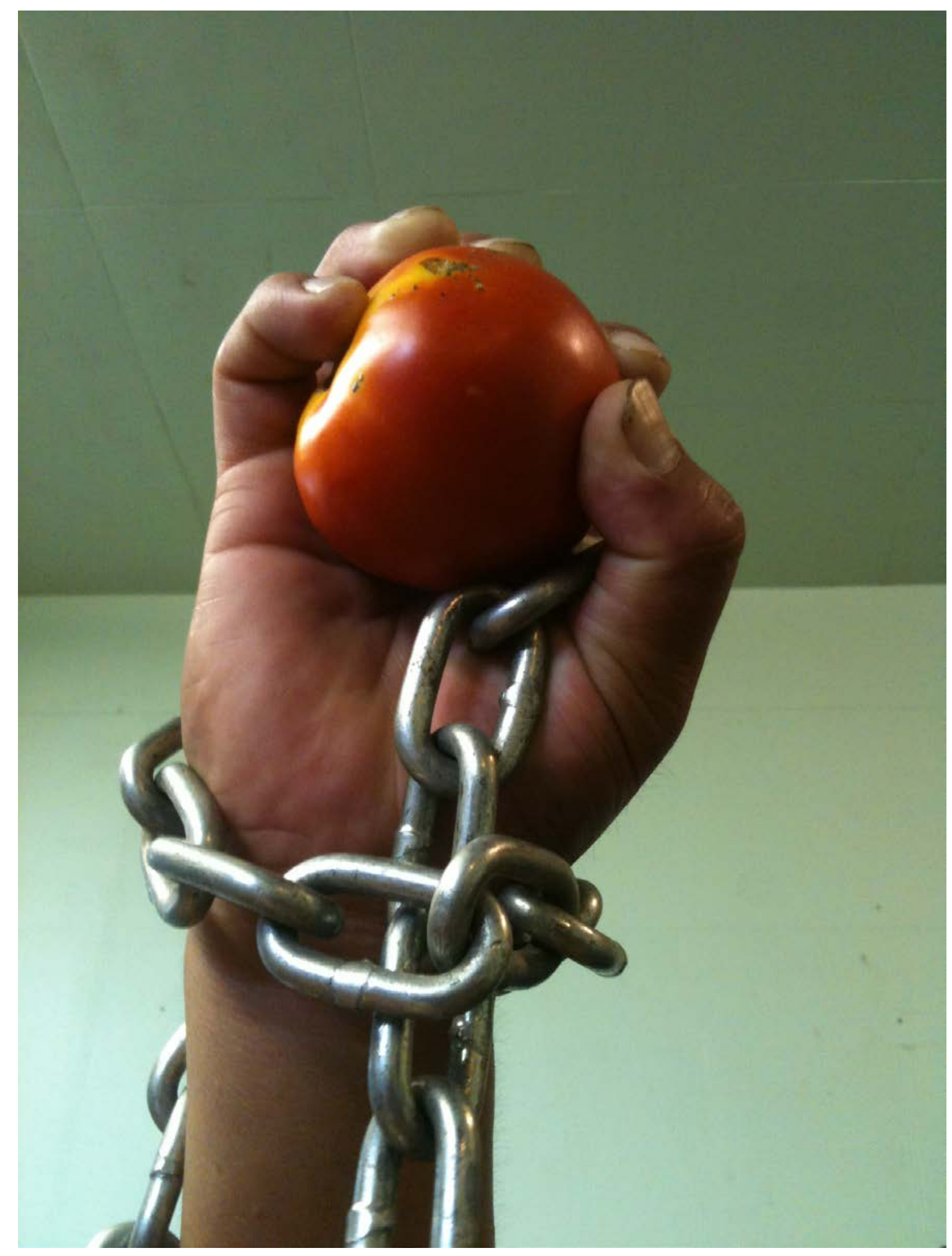




\section{HARVESTINC FREEDOW}

THE YEAR 2016 IS THE 50TH YEAR THAT MIGRANT FARMWORKERS HAVE BEEN

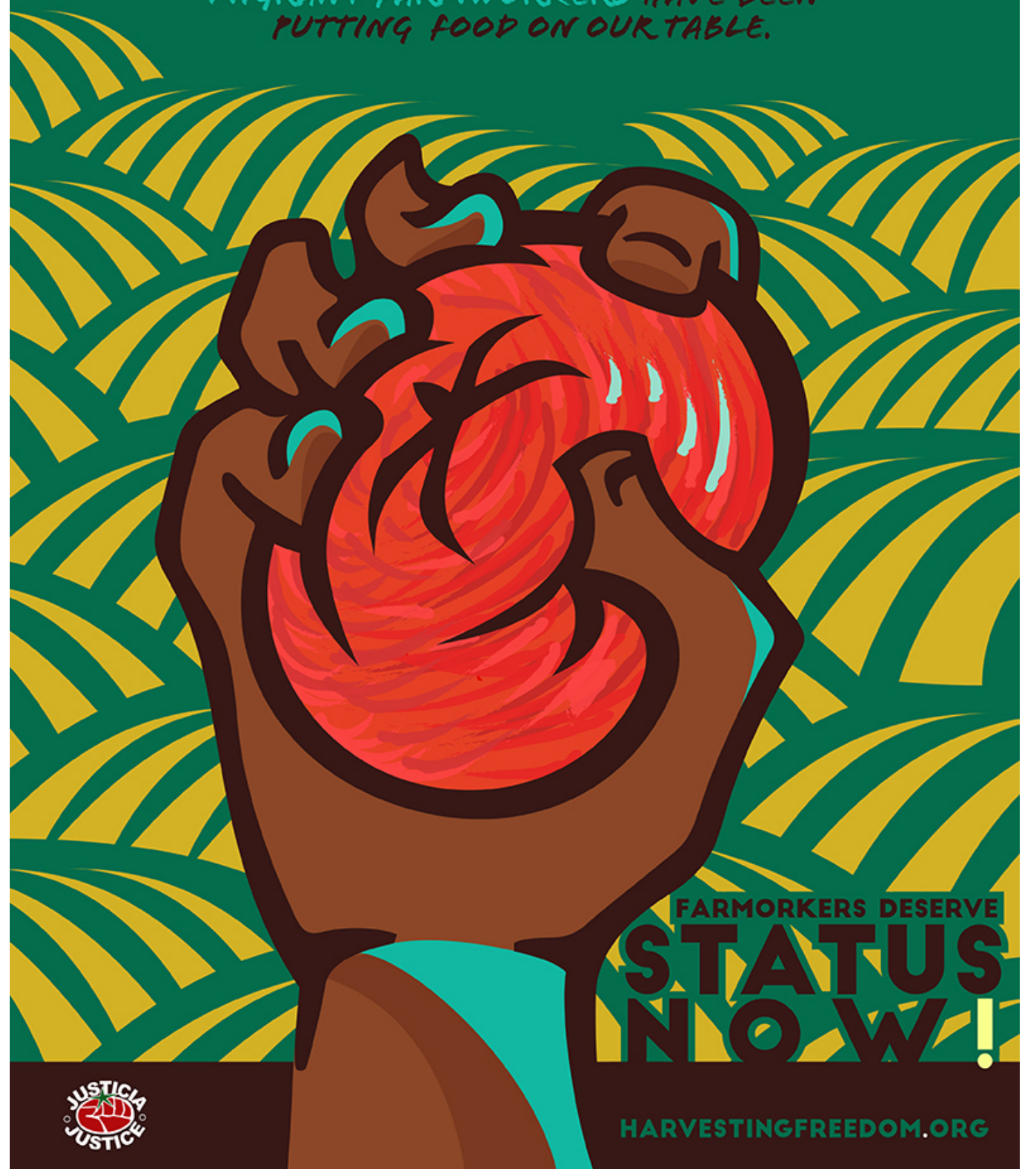

